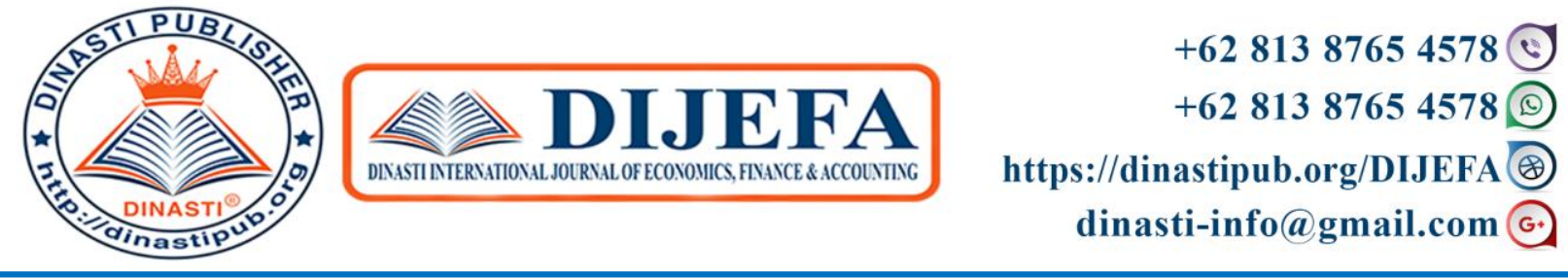

\title{
THE EFFECT OF CAPITAL STRUCTURE, COMPANY GROWTH, AND INFLATION ON FIRM VALUE WITH PROFITABILITY AS INTERVENING VARIABLE (STUDY ON MANUFACTURING COMPANIES LISTED ON BEI PERIOD 2014 - 2018)
}

Maya Topani Suzulia' ${ }^{1}$, Sudjono ${ }^{2}$, Ahmad Badawi Saluy ${ }^{3}$

${ }^{1,2,3)}$ Universitas Mercu Buana, Jakarta, Indonesia

ARTICLE INFORMATION

Received: $10^{\text {th }}$ April 2020

Revised: $18^{\text {th }}$ April 2020

Issued: $26^{\text {th }}$ April 2020

Corresponding author:

Maya Topani Suzulia

E-mail:

${ }^{1}$ mayatopanisuzulia@yahoo.com

${ }^{2}$ sudjono@mercubuana.ac.id

3badawi_saluy@yahoo.co.id

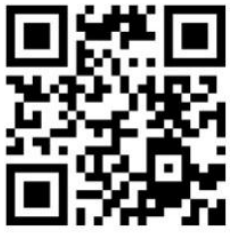

DOI: $10.38035 /$ DIJEFA
Abstract: The purpose of this research is to test and analyze the effect of capital structure, company growth, and inflation on firm value with profitability as intervening variable. The population in this research is manufacturing companies listed on the Indonesia Stock Exchange in 2014 - 2018 totaling 174 companies. Determination of the sample is selected by purposive sampling. Out of 174 populations, only 27 samples were selected. The type of research data is panel data. Path analysis was chosen as the method of data analysis. The results shows that partially capital structure has a significant effect on firm value, company growth and inflation have no significant effect on firm value, capital structure has a significant effect on profitability, company growth and inflation have no significant effect on profitability, profitability has a significant effect on firm value. Profitability mediates the effect of capital structure on firm value, profitability does not mediate the effect of company growth and inflation on firm value.

Keywords: Firm Value, Capital Structure, Company Growth, Inflation, Profitability

\section{INTRODUCTION}

A company's main goal is to maximize the company's wealth or value. Reflections on company performance can be known from the firm value. PBV (Price to Book Value) is one of the proxy for calculating firm value. The high PBV ratio indicates the company's good performance, usually a good PBV is $>1$ which means the market value of the stock $>$ book value. PBV of manufacturing companies that were sampled in this study during 2014-2018 period moved fluctuatively. The highest average PBV is in $2017=6.19$, and the lowest is in $2018=4.40$. This fluctuating PBV movement can be caused by fluctuating DER and PTA 
movements. On the IDX, Manufacturing Companies are divided into 3 sectors: Basic Industry and Chemicals, Miscellaneous Industry, and Consumer Goods Industry. A strong source of funding is the key to achieving the company's main goal of maximizing firm value. The company's capital is divided into 2 sources: internal and external. The combination of capital must be very calculated, with reference to the benefits obtained more than interest expense to be paid. A company must use a combination of capital structure that is appropriate and used optimally in order to achieve higher benefits from the use of debt than the interest expense that must be paid by the company. Debt to Equity Ratio is a proxy in calculating the company's capital structure. According to Trade-off theory, an increase in DER will increase profits, if debt with an increasing amount is used appropriately. The problem is, on the IDX there are several Manufacturing Companies which DER is $>1$, where normally DER is $<100 \%$ or $<1$. It means debt is not higher than equity. For example, there are 10 Manufacturing Companies that have DER > 1, from a total of 27 Manufacturing Companies samples in this research. The results of Andrian's (2012) research, concluded that firm value is significantly affected by capital structure.

The growth of manufacturing companies in Indonesia moved fluctuatively. This can be seen from the Change in its Total Assets, some are increase, decrease, and even decrease drastically. Safrida's research results (2008), concluded the firm value is not significantly influenced by company growth.

One element of firm value creation is profitability, because it symbolizes the company's prospects going forward. The profitability of a company can be proxied by Return On Equity. The high ROE means high profitability, because the rate of return is also getting higher. ROE in manufacturing companies in Indonesia moves fluctuatively, some are increase, decrease, and even decreasing from year to year. Dhani's research results (2017), concluded that firm value is significantly influenced by profitability.

In addition to internal factors, the firm value can also influenced by external factors. Inflation is used as an external factor in this research. Hamidah's research results (2015), concluded the firm value is not significantly influenced by inflation and its direction is negative.

\section{LITERATURE REVIEW}

Firm Value. According to Martin (2010), firm value is the market value or price that applies to the company's common stock. Firm value can be measured by Price Earning Ratio, Price to Book Value and Tobin's Q.

Capital Structure. According to Weston and Copeland (1996), capital structure is permanent financing consisting of long-term debt, preferred shares, and shareholder capital. Types of capital structure theories: Traditional Approach Theory, MM (without tax and with tax), Trade Off Theory, Miller Model, Pecking Order \& Signaling. Ratios for measuring capital structure: DAR, DER, LDER.

Company Growth. According to Brigham and Houston (2001), company growth is the change in annual assets of total assets.

Inflation. According to Bank Indonesia, inflation is defined as an increase in prices in general and continuously within a certain period. Types of inflation are mild, moderate, severe inflation, and hyperinflation.

Profitability. According to Weston and Copeland (1997), Profitability is how far a company has managed to obtain profits on sales and investment. 
Figure 2.Framework

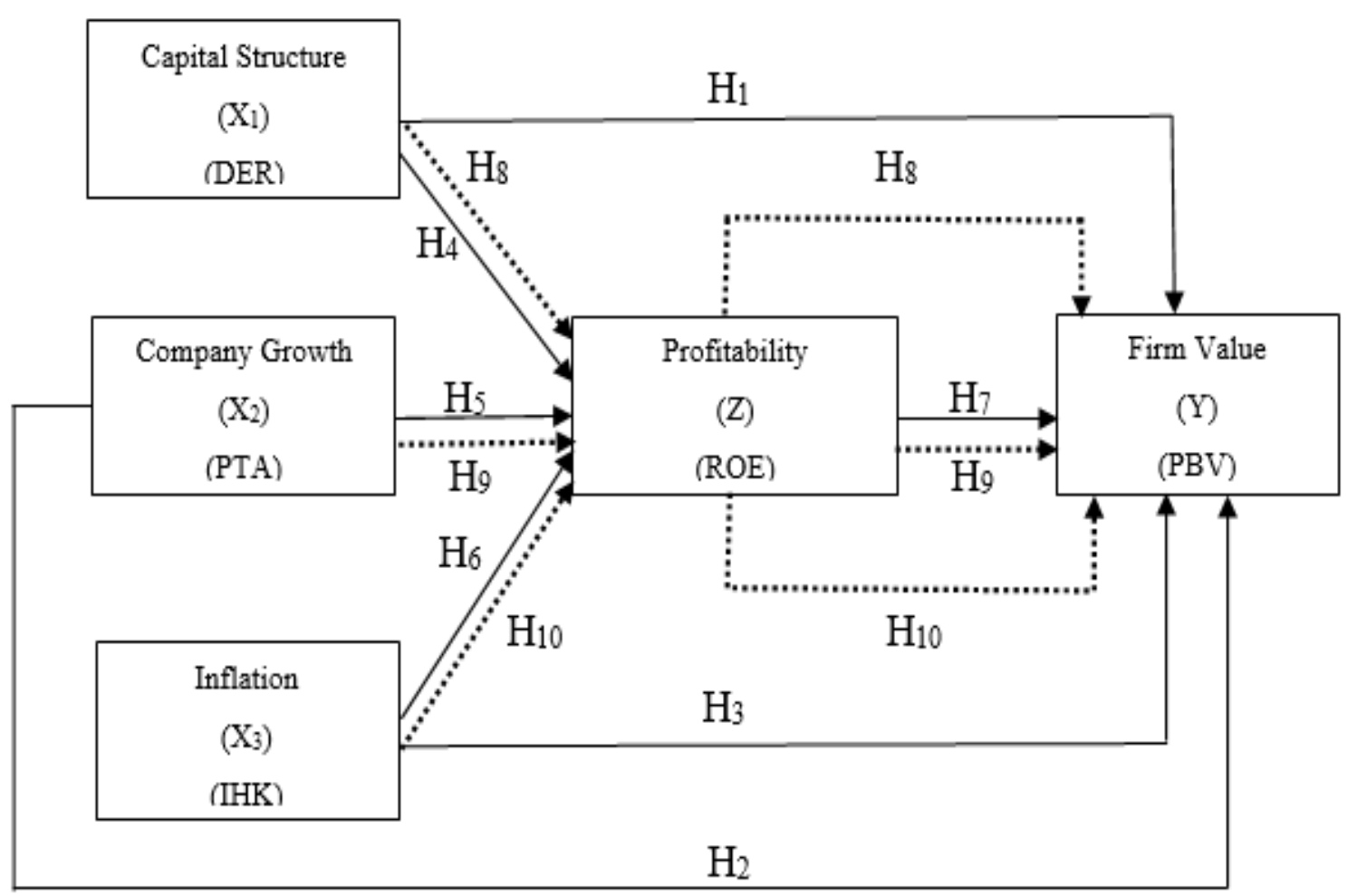

\section{RESEARCH METHODS}

Types of research

Associative research with the form of causal relations with the aim to determine the relationship between 2 variables / more. This type of research is quantitative research.

\section{Variable Measurement}

Table 3.1 Measurement of Variables

\begin{tabular}{cccc}
\hline Variable & Proxy & $\begin{array}{c}\text { Scale of } \\
\text { Measurement }\end{array}$ & Formula \\
$\begin{array}{c}\text { Firm Value } \\
(\mathrm{Y})\end{array}$ & PBV & Ratio & $\mathrm{PBV}=\frac{\text { Price per Share }}{\text { Book Value per Share }}$ \\
\hline $\begin{array}{c}\text { Capital } \\
\text { Structure } \\
\left(\mathrm{X}_{1}\right)\end{array}$ & DER & Ratio & $\mathrm{DER}=\frac{\text { Total Debt }}{\text { Total Equity }}$ \\
\hline $\begin{array}{c}\text { Company } \\
\text { Growth } \\
\left(\mathrm{X}_{2}\right)\end{array}$ & PTA & Ratio & PTA $=\frac{\text { Total Asset } \text { Total Asset }_{\mathrm{t}-1}}{\text { Total Asset }_{\mathrm{t}-1}}$ \\
\hline
\end{tabular}




\begin{tabular}{cccc}
\hline $\begin{array}{c}\text { Inflation } \\
\left(\mathrm{X}_{3}\right)\end{array}$ & $\mathrm{IHK}$ & Ratio & $\mathrm{IHK}=\frac{\mathrm{IHK}_{\mathrm{n}}-\mathrm{IHK}_{0} \times 100 \%}{\mathrm{IHK}_{0}}$ \\
\hline $\begin{array}{c}\text { Profitability } \\
(\mathrm{Z})\end{array}$ & ROE & Ratio & $\mathrm{ROE}=\frac{\text { Net Profit }}{\text { Total Equity }}$ \\
\hline
\end{tabular}

\section{Population and Sample}

Research population: Manufacturing companies listed on the Indonesia Stock Exchange in the 2014-2018 period.

Purposive sampling was chosen to determine the sample of this research, namely the selection of samples with specific criteria and systematic. The criteria are:

Table 3.2 Sample Selection Criteria

\begin{tabular}{llc}
\hline No. & \multicolumn{1}{c}{ Criteria } & Total \\
& $\begin{array}{l}\text { All Manufacturing Companies listed on the } \\
\text { IDX until 2019 }\end{array}$ & 174 \\
\hline 1 & $\begin{array}{l}\text { Manufacturing Companies that have been } \\
\text { and are still listed on the Indonesia Stock } \\
\text { Exchange (IDX) in the last 5 years, or in the } \\
\text { period 2014-2018 }\end{array}$ & $(43)$ \\
\hline 2 & $\begin{array}{l}\text { Manufacturing Companies that published } \\
\text { their financial statements during the 2014- } \\
\text { 2018 period }\end{array}$ & $(43)$ \\
\hline 3 & $\begin{array}{l}\text { Manufacturing Companies that have } \\
\text { complete data needed in this study }\end{array}$ & $(6)$ \\
\hline 4 & $\begin{array}{l}\text { Manufacturing Companies that DER, PTA, } \\
\text { ROE are not minus }\end{array}$ & $(55)$ \\
\hline & Selected Samples & $\mathbf{2 7}$ \\
\hline
\end{tabular}

Based on the above criteria, 27 samples were selected. The 27 Manufacturing Companies are:

Table 3.3 Samples of Manufacturing Companies

\begin{tabular}{llll} 
No. & Stock Name & \multicolumn{1}{c}{ Company Name } & \multicolumn{1}{c}{ Listed Date } \\
1 & AMFG & Asahimas Flat Glass Tbk. & 8-Nov-1995 \\
\hline 2 & ARNA & Arwana Citramulia Tbk. & 17-Jul-2001 \\
\hline 3 & DPNS & Duta Pertiwi Nusantara Tbk. & 8-Aug-1990 \\
\hline 4 & IGAR & Champion Pacific Indonesia Tbk & 5-Nov-1990 \\
\hline 5 & INCI & Intanwijaya Internasional Tbk & 24-Jul-1990 \\
\hline
\end{tabular}




\begin{tabular}{|c|c|c|c|}
\hline 6 & ISSP & Steel Pipe Industry of Indones & 22-Feb-2013 \\
\hline 7 & JPFA & Japfa Comfeed Indonesia Tbk. & 23-Oct-1989 \\
\hline 8 & SMBR & Semen Baturaja (Persero) Tbk. & 28-Jun-2013 \\
\hline 9 & SMGR & Semen Indonesia (Persero) Tbk. & 8-Jul-1991 \\
\hline 10 & ASII & Astra International Tbk. & 4-Apr-1990 \\
\hline 11 & BATA & Sepatu Bata Tbk. & 24-Mar-1982 \\
\hline 12 & KBLI & KMI Wire \& Cable Tbk. & 6-Jul-1992 \\
\hline 13 & PBRX & Pan Brothers Tbk. & 16-Aug-1990 \\
\hline 14 & RICY & Ricky Putra Globalindo Tbk & 22-Jan-1998 \\
\hline 15 & SMSM & Selamat Sempurna Tbk. & 9-Sep-1996 \\
\hline 16 & SRIL & Sri Rejeki Isman Tbk. & 17-Jun-2013 \\
\hline 17 & DLTA & Delta Djakarta Tbk. & 12-Feb-1984 \\
\hline 18 & DVLA & Darya-Varia Laboratoria Tbk. & 11-Nov-1994 \\
\hline 19 & HMSP & H.M. Sampoerna Tbk. & 15-Aug-1990 \\
\hline 20 & ICBP & Indofood CBP Sukses Makmur Tbk & $7-$ Oct-2010 \\
\hline 21 & KAEF & Kimia Farma (Persero) Tbk. & 4-Jul-2001 \\
\hline 22 & KLBF & Kalbe Farma Tbk. & 30-Jul-1991 \\
\hline 23 & MYOR & Mayora Indah Tbk. & 4-Jul-1990 \\
\hline 24 & TCID & Mandom Indonesia Tbk. & 30-Sep-1993 \\
\hline 25 & TSPC & Tempo Scan Pacific Tbk. & 17-Jun-1994 \\
\hline 26 & ULTJ & Ultra Jaya Milk Industry \& Tra & 2-Jul-1990 \\
\hline 27 & UNVR & Unilever Indonesia Tbk. & 11-Jan-1982 \\
\hline
\end{tabular}

(Source : www.idx.co.id, processed)

\section{Data Source}

Data sources used are secondary data: DER, PTA, PBV, ROE which sources are from Annual Report Manufacturing Companies listed on the IDX, and for Inflation data (CPI) sourced from the Bank Indonesia website during 2014-2018.

\section{Data Type}

Data type: panel data. The analysis will be conducted with a time span of 5 years from 2014 to 2018. Taking this time span is a time span by assuming that the data taken is data with the last condition.

\section{Data Analysis Method Using SPSS Version 22.}

\section{Path Analysis}

Path analysis is used to analyze the pattern of relationships between variables with the aim of knowing the direct and indirect effects of a set of independent variables on the dependent variable. 
The path analysis model used can be described in the two structural equation, namely:

$$
\begin{aligned}
& \text { ROE }=\beta_{1} \text { DER }+\beta_{2} \text { PTA }+\beta_{3} \text { IHK }+\mathbf{e}_{1} \ldots \ldots \text { (1) } \\
& \text { PBV }=\beta_{4} \text { ROE }+\beta_{5} \text { DER }+\beta_{6} \text { PTA }+\beta_{7} \text { IHK }+e_{2} \ldots . . \text { (2) } \\
& \text { Information: } \\
& \text { ROE = Profitability } \\
& \mathrm{PBV}=\text { Firm Value } \\
& \beta=\text { Regression coefficient } \\
& \text { DER = Capital Structure proxied by DER } \\
& \text { PTA = Company Growth proxied by PTA } \\
& \text { IHK = Inflation proxied by IHK } \\
& \mathrm{e}=\text { Error }
\end{aligned}
$$

\section{Hypothesis test}

\section{T test (partial)}

$\mathrm{T}$ test explains how far the influence of one independent variable individually in explaining the variation of the dependent variable. The significance level used was $0.05(\alpha=5 \%)$ (Ghozali, 2011). The hypothesis is rejected or accepted with the provisions:

1. If the significance value of $\mathrm{t}>0.05$ means that $\mathrm{H}_{0}$ is accepted; $\mathrm{H}_{1}$ is rejected (regression coefficient is not significant). This means that partially the independent variable has no significant effect on the dependent variable.

2. If the significance value of $\mathrm{t} \leq 0.05$ means that $\mathrm{H}_{0}$ is rejected; $\mathrm{H}_{1}$ is accepted (regression coefficient is significant). This means that partially the independent variable has a significant effect on the dependent variable.

\section{Uji Sobel}

This study uses a mediating / intervening variable: profitability. The Sobel Test is used to test the mediation hypothesis, how it works by testing the strength of the indirect effect $\mathrm{X}_{1}, \mathrm{X}_{2}, \mathrm{X}_{3}$ on $\mathrm{Y}$ through mediation $\mathrm{M}$. The calculation is done by multiplying the path:

$$
\begin{aligned}
\text { 1. } X_{1} & \rightarrow M(a) \\
M & \rightarrow Y(b) \\
\text { 2. } X_{2} & \rightarrow M(c) \\
M & \rightarrow Y(d=b) \\
\text { 3. } X_{3} & \rightarrow M(e) \\
M & \rightarrow Y(f=b)
\end{aligned}
$$

Standard error $\mathrm{a}=\mathrm{Sa}$; Standard error $\mathrm{b}=\mathrm{Sb}$; Standard error $\mathrm{c}=\mathrm{Sc}$; Standard error $\mathrm{d}=\mathrm{Sd}$; Standard error e $=\mathrm{Se}$; Standard error $\mathrm{f}=\mathrm{Sf}$.

Standard error indirect effect $\mathrm{ab}=\mathrm{Sat} ; \mathrm{cd}=\mathrm{Scd}$, ef $=$ Sef. The formula is:

$$
\begin{aligned}
& \mathrm{Sab}=\sqrt{ } \mathrm{b}^{2} \mathrm{Sa}^{2}+\mathrm{a}^{2} \mathrm{Sb}^{2}+\mathrm{Sa}^{2} \mathrm{Sb}^{2} \\
& \mathrm{Scd}=\sqrt{\mathrm{d}^{2}} \mathrm{Sc}^{2}+\mathrm{c}^{2} \mathrm{Sd}^{2}+\mathrm{Sc}^{2} \mathrm{Sd}^{2} \\
& \mathrm{Sef}=\sqrt{ } \mathrm{f}^{2} \mathrm{Se}^{2}+\mathrm{e}^{2} \mathrm{Sf}^{2}+\mathrm{Se}^{2} \mathrm{Sf}^{2}
\end{aligned}
$$

$\mathrm{t}$ value for the coefficients ab, cd and ef, the formula is: 


$$
\begin{aligned}
& t=\frac{a b}{S a b} \\
& t=\frac{c d}{\text { Scd }} \\
& t=\frac{\text { ef }}{\text { Sef }}
\end{aligned}
$$

The conclusion is:

$\mathrm{t}$ value $>\mathrm{t}$ table means there is a mediating effect (Ghozali, 2016).

\section{F Test (Simultaneous)}

The F test explains whether all the independent variables in the model have a simultaneous effect on the dependent variable. The significance level used was $0.05(\alpha=5 \%)$ (Ghozali, 2011). The hypothesis is rejected or accepted with the provisions:

1. If the significance value $\mathrm{F}>0.05$ or $\mathrm{F}$ value $<\mathrm{F}$ table means $\mathrm{H}_{0}$ is accepted; $\mathrm{H}_{1}$ is rejected (regression coefficient is not significant). This means that simultaneously all independent variables have no significant effect on the dependent variable.

2. If the significance value $\mathrm{F} \leq 0.05$ or $\mathrm{F}$ value $>\mathrm{F}$ table means $\mathrm{H}_{0}$ is rejected; $\mathrm{H}_{1}$ is accepted (regression coefficient is significant). This means that simultaneously all independent variables have a significant effect on the dependent variable.

\section{Determination Coefficient Analysis $\left(\mathbf{R}^{2}\right)$}

Adjusted $\mathrm{R}^{2}$ is used for the determination test in this research. The interpretation of the results is as follows:

1. If the value of Adjusted $\mathrm{R}^{2}$ is getting closer to 1 it means that the effect of the independent variables gives almost all the information needed in estimating the variation of the dependent variable.

2. If the value of Adjusted $\mathrm{R}^{2}$ is getting closer to 0 it means that the smaller contribution made by the independent variables on the dependent variable.

\section{RESEARCH RESULTS AND DISCUSSIONS}

Path Analysis

Calculation of Path Coefficient

Equation 1: ROE = 0.368 DER - 0.079 PTA + 0.053 IHK + 0.927

Equation 2: PBV = 0.916 ROE + 0.089 DER - 0.007 PTA - 0.040 IHK + 0.308

Based on Equation 1 and Equation 2 above, a Path Chart can be made as follows:

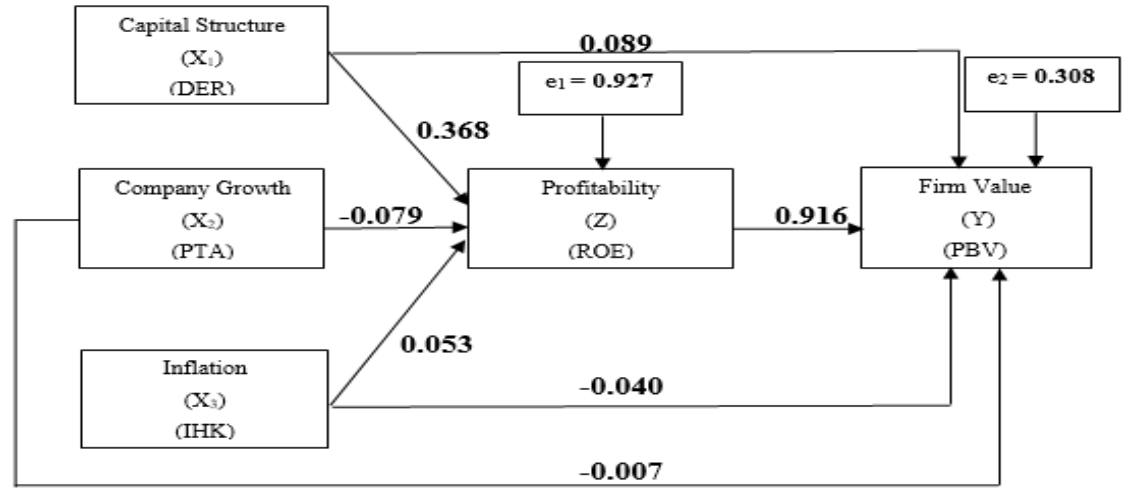


Hypothesis Test

T Test (Partial)

Table 4.1 Calculation Results of $t$ Test for Equation 1 Coefficients $^{\mathrm{a}}$

\begin{tabular}{|c|c|c|c|c|c|c|}
\hline \multirow{2}{*}{\multicolumn{2}{|c|}{ Model }} & \multicolumn{2}{|c|}{ Unstandardized Coefficients } & \multirow{2}{*}{$\begin{array}{c}\text { Standardized } \\
\text { Coefficients } \\
\text { Beta } \\
\end{array}$} & \multirow[b]{2}{*}{$\mathrm{t}$} & \multirow[b]{2}{*}{ Sig. } \\
\hline & & B & Std. Error & & & \\
\hline \multirow[t]{4}{*}{1} & (Constant) & 6.401 & 7.328 & & .874 & .384 \\
\hline & Capital Structure & 13.891 & 3.073 & .368 & 4.521 & .000 \\
\hline & Company Growth & -.164 & .169 & -.079 & -.973 & .332 \\
\hline & Inflation & .879 & 1.345 & .053 & .654 & .514 \\
\hline
\end{tabular}

a. Dependent Variable: Profitability

Table 4.2 Calculation Results of $t$ Test for Equation 2

Coefficients $^{\mathrm{a}}$

\begin{tabular}{|c|c|c|c|c|c|c|}
\hline \multirow{2}{*}{\multicolumn{2}{|c|}{ Model }} & \multicolumn{2}{|c|}{ Unstandardized Coefficients } & \multirow{2}{*}{$\begin{array}{c}\text { Standardized } \\
\text { Coefficients } \\
\text { Beta } \\
\end{array}$} & \multirow[b]{2}{*}{$\mathrm{t}$} & \multirow[b]{2}{*}{ Sig. } \\
\hline & & $\mathrm{B}$ & Std. Error & & & \\
\hline \multirow[t]{5}{*}{1} & (Constant) & -2.667 & 1.200 & & -2.223 & .028 \\
\hline & Capital Structure & 1.653 & .539 & .089 & 3.064 & .003 \\
\hline & Company Growth & -.007 & .028 & -.007 & -.250 & .803 \\
\hline & Inflation & -.324 & .220 & -.040 & -1.473 & .143 \\
\hline & Profitability & .448 & .014 & .916 & 31.386 & .000 \\
\hline
\end{tabular}

a. Dependent Variable: Firm Value

Significance Level $=0.05$

\begin{tabular}{cccl} 
No. & t value & Significance & \multicolumn{1}{c}{ Conclusion } \\
1 & 3.064 & 0.003 & $\begin{array}{l}\mathrm{H}_{1} \text { accepted (Capital Structure has a significant effect } \\
\text { on Firm Value) }\end{array}$ \\
\hline 2 & -0.250 & 0.803 & $\begin{array}{l}\mathrm{H}_{2} \text { rejected (Company Growth has no significant } \\
\text { effect on Firm Value) }\end{array}$ \\
\hline 3 & -1.473 & 0.143 & $\begin{array}{l}\mathrm{H}_{3} \text { rejected (Inflation has no significant effect on } \\
\text { Firm Value) }\end{array}$ \\
\hline 4 & 4.521 & 0.000 & $\begin{array}{l}\mathrm{H}_{4} \text { accepted (Capital Structure has a significant effect } \\
\text { on Profitability) }\end{array}$ \\
\hline
\end{tabular}




\begin{tabular}{cccl}
\hline 5 & -0.973 & 0.332 & $\begin{array}{l}\mathrm{H}_{5} \text { rejected (Company Growth has no significant } \\
\text { effect on Profitability) }\end{array}$ \\
\hline 6 & 0.654 & 0.514 & $\begin{array}{l}\mathrm{H}_{6} \text { rejected (Inflation has no significant effect on } \\
\text { Profitability) }\end{array}$ \\
\hline 7 & 31.386 & 0.000 & $\begin{array}{l}\mathrm{H}_{7} \text { accepted (Profitability has a significant effect on } \\
\text { Firm Value) }\end{array}$ \\
\hline
\end{tabular}

\section{Sobel Test}

To test Hypothesis 8 through 10, the Sobel Test is used

Significance Level $=0.05$

\begin{tabular}{cccl}
\hline No. & t value & t table & \multicolumn{1}{c}{ Conclusion } \\
8 & 3.216 & 1.96 & $\begin{array}{l}\mathrm{H}_{8} \text { accepted (Profitability mediates the effect of Capital } \\
\text { Structure on Firm Value) }\end{array}$ \\
\hline 9 & -12.167 & 1.96 & $\begin{array}{l}\mathrm{H}_{9} \text { rejected (Profitability does not mediate the effect of } \\
\text { Company Growth on Firm Value) }\end{array}$ \\
\hline 10 & 1.085 & 1.96 & $\begin{array}{l}\mathrm{H}_{10} \text { rejected (Profitability does not mediate the effect of } \\
\text { Inflation on Firm Value) }\end{array}$ \\
\hline
\end{tabular}

F Test (Simultaneous)

Table 4.3 Calculation Results of $F$ Test for Equation 1

\begin{tabular}{|c|c|c|c|c|c|c|}
\hline \multicolumn{7}{|c|}{ ANOVA $^{\mathrm{a}}$} \\
\hline & & Sum of Squares & Df & Mean Square & $\mathrm{F}$ & Sig. \\
\hline \multirow[t]{3}{*}{1} & Regression & 10540.698 & 3 & 3513.566 & 7.075 & $.000^{\mathrm{b}}$ \\
\hline & Residual & 65060.772 & 131 & 496.647 & & \\
\hline & Total & 75601.470 & 134 & & & \\
\hline
\end{tabular}
a. Dependent Variable: Profitability
b. Predictors: (Constant), Inflation, Capital Structure, Company Growth

Table 4.4 Calculation Results of $F$ Test for Equation 2

ANOVA $^{\mathrm{a}}$

\begin{tabular}{|ll|r|r|r|c|c|}
\hline Model & & Sum of Squares & \multicolumn{1}{c|}{ df } & Mean Square & F & Sig. \\
\hline 1 & Regression & 16332.066 & 4 & 4083.017 & 308.559 & $.000^{\mathrm{b}}$ \\
& Residual & 1720.229 & 130 & 13.233 & & \\
& Total & 18052.295 & 134 & & & \\
\hline
\end{tabular}
a. Dependent Variable: Firm Value
b. Predictors: (Constant), Profitability, Inflation, Company Growth, Capital Structure 
Significance Level $=0.05$

\begin{tabular}{|c|c|c|c|}
\hline No. & F Value & Significance & Conclusion \\
\hline 1 & 7.075 & 0.000 & $\begin{array}{l}\text { Capital Structure, Company Growth, and Inflation } \\
\text { simultaneously have a significant effect on } \\
\text { Profitability }\end{array}$ \\
\hline 2 & 308.559 & 0.000 & $\begin{array}{l}\text { Capital Structure, Company Growth, Inflation, and } \\
\text { Profitability simultaneously have a significant effect } \\
\text { on Firm Value }\end{array}$ \\
\hline
\end{tabular}

\section{Determination Coefficient Analysis}

Table 4.5 Adjusted $\mathbf{R}^{2}$ Equation 1

\begin{tabular}{|l|c|r|r|c|}
\hline & Model & \multicolumn{1}{|c|}{ R ummary } \\
\hline 1 & $.373^{\mathrm{a}}$ & .139 & $\begin{array}{c}\text { Adjusted R } \\
\text { Square }\end{array}$ & $\begin{array}{c}\text { Std. Error of the } \\
\text { Estimate }\end{array}$ \\
\hline 1 & & .120 & 22.28558 \\
\hline
\end{tabular}

a. Predictors: (Constant), Inflation, Capital Structure, Company Growth

The coefficient of determination (Adjusted $\mathrm{R}^{2}$ ) $=0.120$ or $12 \%$. This means that the profitability variable can be explained by the variables of capital structure, company growth, and inflation by $12 \%$, and the remaining $88 \%$ is explained by other factors outside the model.

\section{Table 4.6 Adjusted $\mathbf{R}^{2}$ Equation 2}

\begin{tabular}{|l|r|r|r|c|}
\hline \multicolumn{1}{|c|}{ Model } & \multicolumn{1}{c|}{ R } & R Square & \multicolumn{1}{c|}{$\begin{array}{c}\text { Adjusted R } \\
\text { Square }\end{array}$} & $\begin{array}{c}\text { Std. Error of the } \\
\text { Estimate }\end{array}$ \\
\hline 1 & $.951^{\mathrm{a}}$ & .905 & .902 & 3.63765 \\
\hline
\end{tabular}

a. Predictors: (Constant), Profitability, Inflation, Company Growth,

\section{Capital Structure}

The coefficient of determination (Adjusted $\mathrm{R}^{2}$ ) $=0.902$ or $90.2 \%$. This means that the firm value variable can be explained by the variables of capital structure, company growth, inflation, and profitability by $90.2 \%$, and the remaining $9.8 \%$ is explained by other factors outside the model.

\section{Discussions}

\section{The Effect of Capital Structure on Firm Value}

According to the $t$ test the firm value (PBV) is significantly and positively influenced by the capital structure (DER), the significance value is 0.003. Appropriate capital structure composition (DER) and used optimally can bring positive value to the firm value. The positive direction here means that the more precise and optimal composition of the company's capital structure (DER), the greater the company's value (PBV) that can be achieved. 
These results are in line with research by Andrian (2012) who concluded the same thing. In the traditional approach theory, optimal capital structure greatly affects the firm value.

\section{The Effect of Company Growth on Firm Value}

According to the $t$ test the firm value (PBV) was not significantly affected by the company's growth (PTA). The direction of the negative relationship in these two variables means that the increase in company growth is not in line with the increase in the firm value, the high growth of the company causing the funds needed are also high. Management of a growing company requires large funds for its operations. The company funds are more focused on supporting the company's growth than the welfare of its shareholders. Therefore, investor more confidence towards established companies than growing companies. That's why even though the company's growth is high, it does not significantly affect to the firm value. This research results are in line with research Safrida (2008).

\section{The Effect of Inflation on FirmValue}

According to the $t$ test the firm value (PBV) is not significantly affected by inflation (CPI). During the research period (2014-2018) inflation that occurred in Indonesia was included in the category of mild inflation because its value $<10 \%$ per year. This mild inflation does not really affect the firm value, because investors focus on the company's idea to keep making profits amid the inflation that hit. Investors believe the company has a strategy and solution to deal with inflation in Indonesia so that it does not affect the firm value, for example, do the efficiency program or cutting unnecessary costs. The results of this research confirm the results of Hamidah's research (2015).

\section{The Effect of Capital Structure on Profitability}

According to the t test profitability (ROE) is significantly and positively influenced by the capital structure (DER). This means that any debt that increases in the company can lead to increased profitability of the company provided the debt is used appropriately. According to Trade off Theory, the use of debt can lead to a reduction in taxes, agency costs that make the company's profitability increase. In the capital structure, the benefits and costs arising from debt must be balanced, additional debt is allowed as long as the benefits > interest expense. If the opposite occurs (interest expense $>$ benefits) additional debt is no longer allowed. The results of this research confirm Andrian's research (2012).

\section{The Effect of Company Growth on Profitability}

According to the $t$ test profitability (ROE) is not significantly affected by company growth (PTA). Large funds are needed by companies that are in the growth stage. Companies usually hold most of their income because of the large funding requirements. Benchmarks for the success of a company is the growth of the company, and can also be used as an investment reference for future growth.

One of the characteristics of a company's growth is the increase in assets which is a sign that the company is expanding. However, the decision to expand must also be considered, if the expansion failed then it impacts on the cost of the company that will increase, which also impacts in a decrease in the company's profitability. The results of this research confirm the results of Andrian's research (2012). 


\section{The Effect of Inflation on Profitability}

According to the $t$ test the profitability (ROE) is not significantly affected by inflation (CPI). This means that if inflation rises it does not always cause the decrease of company's profitability. During the research period (2014-2018) inflation that occurred in Indonesia was included in the category of mild inflation, its value $<10 \%$ per year. This inflation has no significant effect on company profitability because investors believe the company has strategies and solutions to deal with mild inflation in Indonesia. The strategy, such as efficiency or cutting unnecessary costs. The results of this research confirm the research of Adyatmika (2017).

\section{The Effect of Profitability on FirmValue}

According to the $t$ test the firm value (PBV) is significantly and positively influenced by profitability (ROE). This means that the increase in company profitability is in line with the increase in the firm value. This research results are in line with research of Andrian (2012). The high profitability indicates the company's good prospects going forward. That's why investors interested for investing in the company, the high of investor interest causes an increase in demand for company shares. If the demand for shares increases, the firm value also increases.

\section{The Effect of Capital Structure on Firm Value with Profitability as intervening variable}

Capital Structure and Firm Value its effect is mediated by profitability. This means that the benefits derived from debt > interest expenses must be paid because of the use of debt. In this case, the company chooses the right combination of capital structure and also used optimally, so that increasing debt can increasing the company's net profit, which means the value of ROE will increase too. The high ROE is used as a special attraction for investors, because ROE is the ratio of returns from funds invested by shareholders. Investor interest has triggered an increase in demand of stock. High stock demand causes a rise in stock prices, so the firm value also rises.

\section{The Effect of Company Growth on Firm Value with Profitability as intervening variable} Company Growth and Firm Value its effect is not mediated by profitability. The company's growth is marked by an increase in total assets. Expansion is a factor that can increase total assets. But the failure of expansion can cause the increasing of company's expense, that impacts in decreasing of the company's profitability. This information is important for investors to make decisions in investing their capital. Because companies that are growing just need a lot of funds for operations. The company funds are more focused on supporting the company's growth than the welfare of its shareholders. Investors usually more confidence towards established companies than growing companies. That's why eventhough the company's growth is high, it does not significantly affect to the firm value, because the profitability obtained is used for company development.

\section{The Effect of Inflation on Firm Value with Profitability as intervening variable}

Inflation and firm value are not mediated by profitability. It means, increasing inflation does not always decreasing company value and profitability. During the research period (2014-2018) inflation that occurred in Indonesia was included in the category of mild inflation, because the value was $<10 \%$ per year. This mild inflation does not really affect the firm value because investors believe the company has a strategy to increasing profitability in the midst of inflation. That strategies, such as by efficiency or cutting costs that are not necessary. With these strategies, we expected that the company's profitability will increase and also followed by an increase of the firm value. 


\section{CONCLUSIONS AND SUGGESTIONS}

\section{Conclusions}

Based on the results of this research the following conclusions are obtained:

1. Capital Structure has a significant effect on Firm Value.

2. Company Growth has no significant effect on Firm Value.

3. Inflation has no significant effect on Firm Value.

4. Capital Structure has a significant effect on Profitability.

5. Company Growth has no significant effect on Profitability.

6. Inflation has no significant effect on Profitability.

7. Profitability has a significant effect on Firm Value.

8. Profitability mediates the effect of Capital Structure on Firm Value.

9. Profitability does not mediate the effect of Company Growth on Firm Value.

10. Profitability does not mediate the effect of Inflation on Firm Value.

\section{Suggestions}

Suggestions related to this research are:

1. For Companies

a. Companies must use a combination of capital structure appropriately and use it optimally. With a careful calculation so that the benefits received from the use of debt $>$ interest costs paid.

b. The decision to expand must be carefully thought out. Expansion can increase company growth due to changes in total assets company, but keep in mind the failure of expansion will add the expense of the company which has an impact on the decrease of profitability.

\section{For Investors}

For investors, the firm value is very important to analyze the company's performance. The high firm value is in line with the high performance of the company. Price to Book Value $(\mathrm{PBV})$ is a proxy for measuring the firm value, a good PBV is generally $>1$, it means the market value stock > the book value. In this research, the value of a manufacturing company is significantly affected by its capital structure and profitability. Therefore, investors must think carefully about these two variables if they want to invest in manufacturing companies as a basis for making the right investment decisions and bringing profits in the future.

3. For Future Researchers

a. Capital structure, company growth, inflation are chosen as independent variables in this research, and profitability is chosen as the intervening variable. The addition of the independent variable is a suggestion for further researchers so this research is more developed or change the intervening variable that significantly affect the firm value.

b. Increase the research period to more than five years or by changing companies in other sectors as case studies such as property and real estate, mining, and others.

\section{REFERENCES}

Abeywardhana. (2015). "Capital Structure and Profitability: an Empirical Analysis of SMEs in the UK". Journal of Emerging Issues in Economics, Finance and Banking (JEIEFB), Vol. 4, Issue 2.

Addae, Albert Amponsah, Michael Nyarko Baasi, dan Daniel Hughes. (2013). "The Effects of Capital Structure on Profitability of Listed Firms in Ghana". European Journal of Business and Management, Vol. 5, No. 31. 
Adyatmika. (2017). "Pengaruh Inflasi dan Leverage Terhadap Profitabilitas dan Return Saham Pada Perusahaan Manufaktur di Bursa Efek Indonesia". Tesis. Fakultas Ekonomi dan Bisnis, Program Pascasarjana. Universitas Udayana. Denpasar.

Agustina, Cahyati dan Anindya Ardiansari. (2015). "Pengaruh Faktor Ekonomi Makro dan Kinerja Keuangan Terhadap Nilai Perusahaan”. Management Analysis Journal 4 (1).

Andrian, Jun. (2012). "Pengaruh Struktur Modal, Pertumbuhan Perusahaan, Capital Expenditure dan Insentif Manajer Terhadap Nilai Perusahaan dengan Profitabilitas Sebagai Variabel Intervening”. Jurnal Bisnis Strategi, Vol. 21, No. 2.

Arowoshegbe, Amos, dan Jeremiah Idialu. (2013). "Capital Structure and Profitability of Quoted Companies in Nigeria”. International Journal of Business and Social Research (IJBSR), Vol. 3, No. 3.

Barakat, Abdallah, dan Hussein Samhan. (2013). "The Effect of Financial Structure, Financial Leverage and Profitability on Industrial Companies Shares Value: Applied Study on a Sample of Saudi Industrial Companies".

Chisti, Khalid Ashraf, Khursheed Ali, dan Mouh-i-Din Sangmi. (2013). "Impact of Capital Structure on Profitability of Listed Companies (Evidence From India)". The USV Annals of Economics and Public Administration, Vol. 13, Issue 1 (17).

Dae, Cheysilia Novita dan Mellyza Silvy. (2015). "Pengaruh Faktor Internal dan Eksternal terhadap Nilai Perusahaan pada Perusahaan Manufaktur yang terdaftar di Bursa Efek Indonesia (BEI)". Artikel Ilmiah, hal 3-19.

Dewi, Ayu Sri Mahatma dan Ary Wirajaya. (2013). "Pengaruh Struktur Modal, Profitabilitas dan Ukuran Perusahaan Pada Nilai Perusahaan”. E-Jurnal Akuntansi Universitas Udayana 4.2, hal 358-372.

Dhani, Isabella Permata dan A.A Gde Satia Utama. (2017). "Pengaruh Pertumbuhan Perusahaan, Struktur Modal, dan Profitabilitas Terhadap Nilai Perusahaan”. Jurnal Riset Akuntansi dan Bisnis Airlangga, Vol. 2, No. 1.

Fajri, Gilang Ramadhan, dan Dwi Asih Surjandari. (2016). "The Influence of Profitability Ratios, Capital Structure and Shareholding Structure Against on Value Company (Empirical Study of Coal Mining Companies Listed on the Stock Exchange of Indonesia Year 2011-2013)". The Accounting Journal of Binaniaga, Vol. 01, No. 02.

Gill, Amarjit, Nahum Biger, dan Neil Mathur. (2011). "The Effect of Capital Structure on Profitability: Evidence from the United States". International Journal of Management, Vol. 28, No. 4, Part 1.

Hamidah, Hartini, dan Umi Mardiyati. (2015). "Pengaruh Inflasi, Suku Bunga BI, Profitabilitas dan Risiko Finansial terhadap Nilai Perusahaan Sektor Properti Tahun 2011 - 2013”. Jurnal Riset Manajemen Sains Indonesia( JRMSI), Vol. 6, No. 1.

Kartika, Risna. (2016). "Pengaruh Inflasi dan Nilai Tukar Rupiah Terhadap Penyaluran Kredit Pada Bank Umum di Indonesia". Tesis. Program Studi Magister Manajemen, Program Pascasarjana. Universitas Widyatama. Bandung.

Kho, Budi. (2017). Pengertian PBV (Price to Book Value) dan Rumus PBV. https://ilmumanajemenindustri.com/pengertian-pbv-price-book-value-rumus-pbv/ (Diakses tanggal 5 April 2019).

Mesquita, Jose Marcos Carvalho de, dan Jose Edson Lara. (2015). "Capital Structure and Profitability: The Brazilian Case". 
Mohammadzadeh et al. (2013). "The Effect of Capital Structure on the Profitability of Pharmaceutical Companies The Case of Iran". Iranian Journal of Pharmaceutical Research, Vol. 12, No. 3, page 573-577.

Mokhova, Natalia, dan Marek Zinecker. (2014). "Macroeconomic Factors and Corporate Capital Structure". Procedia - Social and Behavioral Sciences, page 530-540.

Parhusip, Hara Agum Gumelar, Topowijono, dan Sri Sulasmiyati. (2016). "Pengaruh Struktur Modal dan Profitabilitas terhadap Nilai Perusahaan (Studi Pada Perusahaan Makanan dan Minuman yang Terdaftar di Bursa Efek Indonesia Periode 2011-2014)". Jurnal Administrasi Bisnis (JAB), Vol. 37, No. 2.

Puspita, Novita Santi. (2010). "Analisis Pengaruh Struktur Modal, Pertumbuhan Perusahaan, Ukuran Perusahaan, dan Profitabilitas terhadap Nilai Perusahaan pada Perusahaan Manufaktur yang terdaftar di Bursa Efek Indonesia Periode 2007 - 2009 (Studi Kasus pada Sektor Industri Food and Beverages)".

Safrida, Eli. (2008). "Pengaruh Struktur Modal dan Pertumbuhan Perusahaan terhadap Nilai Perusahaan pada Perusahaan Manufaktur di Bursa Efek Jakarta”. Tesis. Program Studi Akuntansi, Program Pascasarjana. Universitas Sumatera Utara. Medan.

Shubita, Mohammad Fawzi, dan Jaafer Maroof Alsawalhah. (2012). "The Relationship between Capital Structure and Profitability”. International Journal of Business and Social Science, Vol. 3, No. 16.

Suryantini, Ni Putu Santi dan I Wayan Edi Arsawan. (2014). "Pengaruh Faktor Eksternal Terhadap Nilai Perusahaan (PBV) dan Harga Saham Terhadap Perusahaan Manufaktur di Bursa Efek Indonesia”. Jurnal Manajemen, Strategi Bisnis dan Kewirausahaan, Vol. 8, No. 2.

Ulya, Himatul. (2014). "Analisis Pengaruh Kebijakan Hutang, Kebijakan Dividen, Profitabilitas, Kinerja Perusahaan dan Keputusan Investasi Terhadap Nilai Perusahaan Pada Perusahaan Manufaktur yang Terdaftar di Bursa Efek Indonesia (BEI) Tahun 2009-2011”.

Umaiyah, Erwin dan M. Noor Salim. (2018). "Rasio Keuangan, Ukuran Perusahaan, Struktur Modal dan Dampaknya Terhadap Nilai Perusahaan Non Perbankan Kategori LQ-45". Jurnal Ilmiah Manajemen \& Bisnis, Vol. 2, No. 3.

Vatavu, Sorana. (2015). "The Impact of Capital Structure on Financial Performance in Romanian Listed Companies". Procedia Economics and Finance, page 1314-1322.

$\mathrm{Xu}$, Jin. (2012). "Profitability and Capital Structure: Evidence from Import Penetration". Journal of Financial Economics.

Zaky, Mubarok Imam, Hartoyo Sri, dan Maulana Tb. Nur Ahmad. (2019). "The Effects of The World CPO Prices, Macroecomony, and Capital Structures on The Profitability of Palm Oil Companies". RJOAS. 